\title{
Discourse Analysis of Argumentative and Persuasive Texts on GO-JEK Advertisement Text
}

\author{
Fadhila Kusumaningrum, Universitas Airlangga
}

\begin{abstract}
Advertisement is a way in promoting something. Advertisement can be either audio, visual or both. Advertisement text is one of persuasive argumentative discourses. In this article, the main object is the advertisement text of one of online transportation providers in Indonesia, GO-JEK. The writer analyzed one of the GO-JEK's advertisements that was installed on the main street in Jakarta and was famously jammed. This study applied Stephen Toulmin's model approach to find out the argument elements of the GOJEK advertisement text. In addition, the writer also implemented communication approach to discover the communication elements in this advertisement. The result shows that there are claim, data, warrant, backing, and rebuttal related to people's life used in this advertisement. The discovered data are assumed used by the copywriter in order to persuade the audiences properly through text.
\end{abstract}

Keywords: advertisement text; argumentative; discourse analysis; persuasive

\section{Introduction}

In arguing, we want that what we say is acceptable to others. Thus, we need to make a sentence that can convince them. Arguments are usually presented in debates, discussions, deliberations or in the form of texts such as opinions. However, arguments can also be found in advertisements. Advertisements usually contain pictures, products and interesting texts that can influence the readers. Nowadays, we live in advertising era, where every space in our lives carries the commercial message (Cattani, 2011). Asemah (2013) stated that advertisement is a kind of communication in paid form which is designed in such way to influence someone in taking an attitude. Not all advertisements are product advertisements; there are also non-product advertisements, such as political party campaigns (Cook, 1992). As mentioned before, the argument discourse aims to convince the partner to agree with the argument. Advertisement is one form to deliver the arguments from one party to a particular party. However, it should be noted how persuasive language is used in advertisement. Persuasive language is very important in determining the success of an advertisement. Some advertisements use certain language styles to attract the readers. For example in dishwashing, drink or food advertisements, the words used in describing the products are too exaggerated. Meanwhile, argumentative discourse is a logical discourse that the given statement must prove something that can be verified. Thus, the language used needs to be adapted to the needs of the target consumers. As technological development, human consumption has also increased. In this modern era, many needs can be accessed by people only through their smartphones; one of them is through online transportation facility. It means that the passengers only use their smart phone to get a ride. GO-JEK is one of the biggest online transportation in Indonesia consisting of three types of fleet offered, GO-JEK (motorcycle taxi), GO-CAR (taxi), and GO-BOX (pick-up car to deliver goods in size and big amount). Among the similar online-based transport companies, GO-JEK tries to attract the attention of potential customers in various ways, whether by giving a promo or displaying advertisements. In this study, the writer chooses GO-JEK advertisements; especially GO-JEK advertisementsin a billboardthat is installed in one of the streets in Jakarta (see Figure 1 in attachment).

\section{Theoretical Framework}

Argumentation is a way of expressing opinions with motivation to influence or change the opinions or attitudes of others. Keraf (1982) mentioned that there is a need for observation to be done by a person before conveying his/her argument. An argument is required to state the strong truth or power to influence the readers' or listeners' attitude. In addition, the need for tools 
that can support the argument is also presented. The tools to influence or to change the readers' or listeners' opinion are evidences that are acceptable for themas correct opinions and conclusions (Winahyu, 2011). Keraf (in Winahyu, 2011) suggested that the evidences are structured in reasoning, namely induction and deduction. Inductive reasoning begins with the elaboration of specific evidence and ends with general evidence. In contrast, deductive reasoning begins with general evidence and ends with special evidence. Hoeken (2011, in Renkema, 2004) distinguished evidence into two types, namely statistical and anecdotal evidence (short story). The statistical evidence is the evidence showing a percentage of an event. This is usually obtained from the relevant authorities, while the anecdotal evidence is presented in sentences that are able to convince someone.

This research utilizes Stephen Toulmin's model approach to find out the pattern of argument in GO-JEK advertisement text. Advertisement text is one of persuasive argumentative discourse that aims to influence a person to do things as desired by the related company. Renkema (2004) argued that the purpose of this form of discourse is to influence the reader in thoughts, feelings and actions. In Stephen Toulmin's model, arguments are seen as claims and other statements (data). Claim is a statement used by authors that contains a belief or truth, whereas, the data is a statement that supports the claim. Between the two statements there is a statement known as warrant. Warrant is a supporting statement containing evidence between data and claims. The supporting evidence of this warrant is also referred as backing. Thus, there is an interrelated relationship between claim and data. In this model, Toulmin included a rebuttal. Rebuttal is a statement which means here a condition of exclusion or denial.

Schema 1. The following model diagram from Stephen Toulmin, in Renkema (2004)

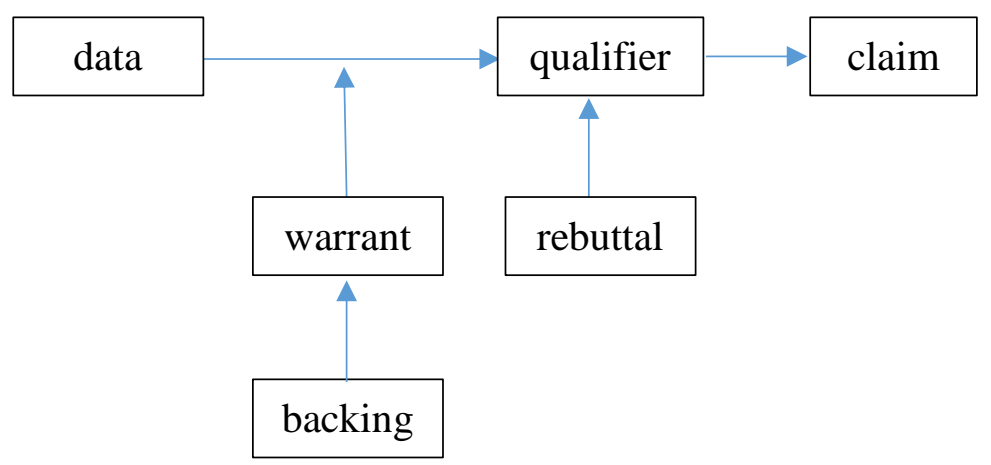

An advertisementcannot be separated from the community. In Renkema (2004), it was stated that there needs to be a socio-psychological approach to be accepted and reassured by the community, which is attitude of communicators or discourse makers, in this case is a copywriter, in facing the problems that arise in society by providing solutions in the form of products offered. Harold Lasswell (1948, in Renkema 2004), mentioned that there are five factors in communication approach; who, what, which channel, whom, and for what impact. The first is who. In conveying something, especially the advertisement that aims to influence the society, the credibility of communicators needs to be considered. Here, whois the person or party who delivers the message.Thus, for advertisements that use persons as the talent, they need to considerate what kind of talents that suit the advertisements the best. Second, what is related to the subject or message that the discourse maker wants to convey. Therefore, there needs to be consideration regarding what messages and which ones should be conveyed. Third, which channel relates to how the discourse maker conveys the discourse in order to be received well. In an advertisement, it should be considered whether the advertisement will be more acceptable if delivered through newspapers, television, radio, internet, pamphlets, billboards, or anything else.Because of that, it is also related to the fourth factor: to whom this advertisement will be delivered. In an advertisement, determining who will receive the discourse is essential. It is related to the way the 
company delivers the message. To this exent, the company can get the expected impact from the advertisements.

\section{Methodology}

This research enforced qualitative descriptive approach to explain the phenomenon. Qualitative (MacDonald, 2009) is used when the data is in the form of words, pictures, or objects. The qualitative descriptive method may have goals of identifying causal effects in specific contexts through ethnography or interpretive techniques (Loeb, 2017). Toulmin's model in this analysis is used to find out the pattern of arguments used by copywriters or text-makers. A text certainly cannot be separated from its context. Thus, the writer also used the communication approach proposed by Harold Laswell (1948, in Renkema, 2004) to find out who, what, which channel, to whom, and for what impact in the advertisement. Hence, the structure of the text and the contents of this advertisement can be implied. Although it is a visual object, the main object in this research is the text contained in the advertisement. The advertisement in this study was taken from one of the advertisements of an online transportation company, GO-JEK. This advertisement was a billboard placed on a main street in Jakarta (see Figure 1 in attachment page). The writer chose this advertisement because in terms of visual, this advertisement is very simple. However, the text was interesting in terms to offer its products without having to use excessive words such as any other advertisement texts that mostly using a particular language style to attract potential customers.

\section{Discussion}

This advertisementis designed by an online transportation, GO-JEK, in the form of large billboard installed in one of Jakarta's main streets. The writer is intriguid in observing this advertisement since this advertisement is only installed in Jakarta, especially on a main street where traffic jam often occurs. Thus, it becomes interesting when this billboard is read by the riders or someone who is stuck in traffic. An advertisement text can not be separated from its creator or better known as a copywriter. In creating an advertisement, a copywriter will see the attitudes and the mental of intended audience to create a text that fits customers' life.

Here is the text of GO-JEK advertisement:

"Hai kamu. Iya, kamu. Coba bayangin deh. Coba bayangin kalau pagi ini bisa nyampe kantor lebih cepet. Buka pintu kantor nggak mesti agak nundukin kepala sambil jalan cepet. Bisa ngopi atau ngeteh dulu di pantry, moodnya jadi enak seharian, zen kalau kata orang-orang. Temen-temen kantor jadi pada nyenengin, tektokan kerjaan jadi lebih cepet, jadi bisa pulang on-time deh.

“Hey, you. Yes, you. Let's imagine. Let's imagine if this morning you could arrive in the office quickly. You should not bow your head and walk fast while opening the office door. You could drink coffee or tea first in the pantry, your mood would be good all day; zen, people say. Your workmates became pleasures, you could do your work faster, so you could go home on-time.

Masih ngebayangin kan?? Oke. Lanjut yaa. Kalau bisa pulang on-time, kamu jadi bisa makan malem bareng anak istri di rumah. Bisa dengerin mereka punya cerita apa hari ini. Eh, si kecil ternyata uda lancar nyanyi Satu-satu Aku Sayang Ibu. Nggak apa-apa deh Ayahnya jadi nomer dua, pikirmu dalam hati. Kaти tau rasa ini, momen ini nggak bisa diungkapin dengan kata-kata. Nggak lama abis itu, kamu bisa tidur dengan senyum, sang istri di sebelahmu juga gitu. Dia bisikin ke kamu kalau dia seneng banget kamu bisa pulang cepet hari ini. Besok paginya, kamu bangun dengan lebih semangat. Kayak dapet energi tambahan entah dari mana. Ajaib tapi nyata. Coba bayangin kalo tiap hari bisa kayak gini. Mari 
kembali ke kenyataan. Dari tadi belom nyampe perempatan Kuningan juga? GOJEK-in aja."

Still imagining, right? Okay. Go ahead. If you could go home on-time, you would have dinner with your children and wife at home. You could hear the stories they have today. Uh, the little one was already fluently singing "Satu-satu Aku Sayang Ibu". It's okay his dad became number two, you think to yourself. You knew this feeling, this moment could not be expressed in words. After that, you could sleep with a smile, with your wife next to you too. She whispered that she's really happy you could go home early today. The next morning, you woke up with more enthusiasm. Like getting extra energy from nowhere. Magical but real. Try to imagine if every day could be like this. Let's get back to reality. Have you reached Kuningan intersection yet? Let's use GO-JEK"

Table 1: First paragraph

\begin{tabular}{|l|l|}
\hline Element & Sentences \\
\hline Claim & $\begin{array}{l}\text { Coba bayangin kalau pagi ini bisa nyampe kantor lebih cepet. } \\
\text { Let's imagine if this morning you could arrive in the office quickly.( } 4^{\text {th }} \\
\text { sentence) }\end{array}$ \\
Warrant & $\begin{array}{l}\text { Bisa ngopi atau ngeteh dulu di pantry } \\
\text { You could drink coffee or tea first in the pantry }\left(6 \mathrm{t}^{\mathrm{t}} \text { sentence }\right) \\
\text { Backing } \\
\text { your mood wadi enak seharian }\end{array}$ \\
$\begin{array}{l}\text { Temen-temen kantor jadi pada } \text { nyenengin, tektokan kerjaan jadi lebih } \\
\text { cepet, jadi bisa pulang on-time deh. } \\
\text { Your workmates became pleasures, you could do your work faster, so } \\
\left.\text { you could go home on-time ( } 7^{\text {th }} \text { sentence }\right)\end{array}$ \\
\hline
\end{tabular}

In the sentences of this paragraph, the copywriter provided data in the form of bisa ngopi atau ngeteh dulu di pantry as a supporting sentence of the claim to give suggestions to the readers who mostly are employees or workers who often leave home early and ignore their breakfast. However, if they are able to get to work faster or earlier, they can have time to drink tea or coffee, which for most office workers, as the copywriter assumed, drinking tea or coffee in the morning can improve the mood to work all day. This statement is written by a copywriter who entered the warrant element and supported by several reinforcing reasons that a good mood can make the blissful conditions in the office, such as friends and workmates become more pleasing. Consequently, the workers can go home on time as well.

Table 2: Second paragraph

\begin{tabular}{|l|l|}
\hline Element & Sentences \\
\hline Claim & $\begin{array}{l}\text { Kalau bisa pulang on-time, kamu jadi bisa makan malem bareng anak istri di } \\
\text { rumah. } \\
\text { If you could go home on time, you would have dinner with your children and } \\
\text { wife at home ( } 3^{\text {rd }} \text { sentence) }\end{array}$ \\
\hline
\end{tabular}


Table 2, cont.

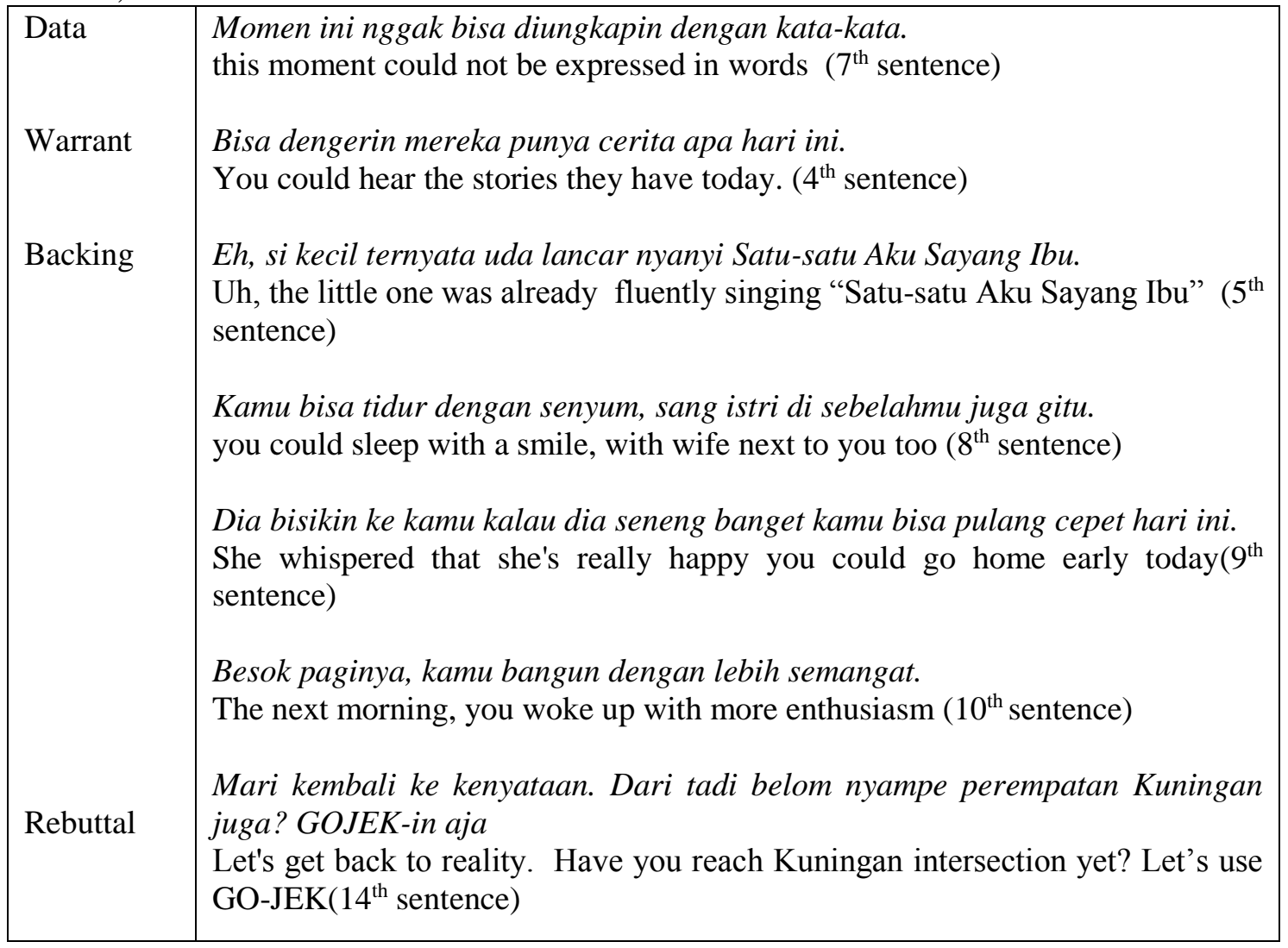

In Table 2, is an explanation of the second paragraph of this advertisement. The claim in second paragraph that the copywriter madeis still related to the previous paragraph, which is about go home on time. In the data, it is written about the precious moments that could possibly occur if they got home early;it is shown in warrant and the evidence is described in backing. However, the rebuttal in this paragraph shows different conditions from the previous sentences.

The explanation of the advertisementtext is divided into two tables above. It can be seen that the argument structure of this text have several elements as mentioned by Stephen Toulmin, that is, claim, data, warrant, backing, and rebuttal. From the tables, there are two sentences that use the word "if". In Toulmin's model, the possible sentences are categorized in the qualifier. However, the writer categorizes it into claim because before explaining a sentence that contains the word "if", there is a sentence that directs the readers to imagine a condition. Below are the referred sentences:

"Coba deh bayangin. Coba bayangin kalau pagi ini bisa nyampe kantor lebih cepet"

"Let's imagine. Let's imagine if this morning you could arrive in the office quickly". ( $1^{\text {st }}$ paragraph, $3^{\text {rd }}$ and $4^{\text {th }}$ sentence)

"Masih ngebayangin kan?? Oke. Lanjut yaa. Kalau bisa pulang on-time, kamu jadi bisa makan malem bareng anak istri di rumah".

"Still imagining, right?? Okay. Go ahead. If you could go home on time, you would have dinner with your children and wife at home." $\left(2^{\text {nd }}\right.$ paragraph, $1^{\text {st }}-3^{\text {rd }}$ sentence)

Thus, for the rebuttal in Table 2, the copywriter wrote, "Mari kembali ke kenyataan. Dari tadi belom nyampe perempatan Kuningan juga? GO-JEK-in aja" as a rebuttal that the readers 
are not in the condition as written in the advertisement text. In broad, if a person did not get stuck on traffic jam, s/he would arrive to the office faster. However, in fact, the readersare stuck in a traffic jam that makes the imaginationno more thanan excpetation. At the end of the sentence, the copywriter wrote, "GO-JEK-in aja" as a persuasive phrase in order to persuade the trapped workers to change their private transportation into GO-JEK to shorten their time as well as to make their life aspleasing as it is written in the advertisement text. Thus, in advertisement texts, the writer categorized it into claim, since a statement believed to be true by the author is expected to be accepted by the readers. In order to make the claim be accepted by the readers, the copywriter also added sentences that can support the argument, which the writer have been categorized into warrant and backing. In consequent, the content of this advertisement text can be accepted by human reasoning.

After discerning the argumentation pattern of advertisement text, the elements outside the text that can affect the copywriter in writing the advertisement text is also examined. An advertisementwill attract the readers if it has social and psychological closeness with the community, especially in target community of the advertisement. For that reason, social and psychological approaches also need to be disclosed. In this research, the writer used the analysis of communication approach to find out the content of the advertisement text based on the social elements of the constituent (Harold Laswell, 1948 in Renkema, 2004).

First, the whois GO-JEK. GO-JEK is a online transportation company that facilitates people to do their activities without congestion on the street that is filled by private vehicles. Next, the what in this text is assumed that GO-JEK wanted to relate to the readers, especially private vehicle users to change their private vehicles into GO-JEK because it is time and energy saving, as well as more practical. Furthermore, it is supported by an application that is easily accessible from smartphones, so the passengers do not need to look for ojek or taxi by the roadside. The which channelis indicated by GO-JEK using billboards to promote their products. This billboard iss installed on one of the main streets in Jakarta. By using a large size of the text, the workers who are trapped in traffic jam indirectly will read the advertisement text in this billboard. After that, the to whomcan be seen from many of GO-JEK users who come from various circles and professions and GO-JEK deliberately used the employees/office workers who are often in a rush and are required to arrive at the office on time as the target of the advertisement. The copywriter chose a male or a father figure to make the text feel close to the readers, in which most workers are men. So, the copywriter wanted to bring the closeness between what s/he wrote with the object or the target market. It is also supported by depictions of activities in the office, about work, colleagues, children, wife, sleep, and home. Therefore, it can be concluded that the copywriter deliberately creates this advertisementfor office workers who must leave early in order not to be late to go to work every day. As for the for what impact, GO-JEK wantedto affectthe riders or drivers to change their transportation into GO-JEK as an alternative transportation rather than a private vehicle that often causes congestion.

Based on the form, the advertisement text is a narrative text. Dymock (2007) stated that narrativeis more than simple lists of sentences or ideas; narratives are stories. Calfee and Drum (1986, in Dymock, 2007) reported that "stories generally tell "what happened"; who did what to whom and why. However, after analyzing and putting it into the argument elements as elucidated above, it can be seen that the aim of this text is actually to persuade. As Hoeken (2011) pointed out, supporting evidence may be statistical and anecdotal in nature. In this text, the copywriter wrote the evidence in the form of short story in persuasive language that tells the story of office workers' daily activities. That way, after knowing who the target of this advertisementis and where the advertisementis installed, the evidence written through this narrative will feel real. Thus, this advertisementwill be very impressive when the readerscan relate it with their personal life. 


\section{Conclusion}

From the analysis above by using Stephen Toulmin's model, it can be seen that the advertisement text has an argumentative discourse pattern that consists of argument elements, such as claim, data, warrant, backing, and rebuttal. Besides argument elements, the writer also implemented a communication approach proposed by Harold Lasswell to discover the intended party and how to make this advertisement be accepted by the target market to raise the expected impact. In addition, it can be seen that the copywriter deliberately made such a text not without reasons. Instead, the copywriterintended to create an interaction between the text and the readers that can bring closeness to the text by reflecting it into the people's live, especially to the workers or employees. Thus, it can be concluded that the text of the GO-JEK advertisement is aimed at people who are stuck in traffic jam to change into GO-JEK as an alternative transportation to avoid traffic jam that their time is not wasted on the road. Consequently, their lives can be happier because they have plenty of time for their family.

\section{References}

Asemah, et.al. 2013. Behind advertising: the language of persuasion. International Journal of Asian Social Science, 3(4), 951-959.

Billboard unik ojek online memukau netizen. 6 iklan ini juga bisa bikin kamu terpukau loh, sahabat trivia!. Available at https://trivia.id/post/billboard-unik-ojek-online-memukaunetizen-6-iklan-ini-juga. (Accessed on June 1, 2018)

Cattani, Annalisa. 2011. Argumentative mechanism in advertising. Forum Artis Rhetoricae, 1, 85-105.

Cook, Guy. 1992. The discourse of advertising. United State of America: Routled.

Dari banyak iklan, kenapa billboard go-jek di kuningan viral?. Available at http://marketeers.com/alasan-billboard-go-jek-viral/. (Accessed on June 1, 2018)

Dymock, S. 2007. Comprehension strategy instruction: teaching narrative text structure awareness. International Reading Association, 61(2), 161-167.

Keraf, G. 1982. ArgumentasidanNarasi. Jakarta: Gramedia.

MacDonald, S., \& Nicola Headlam. 2009. Research Methods Handbook: Introductory Guide to Research Methods for Social Research. Manchester: Centre for Local Economic Strategies.

Renkema, Jan. 2004. Introduction to discourse studies. Philadelphia: John Benjamins Publishing Company.

Rottenberg, A. 1988. Elements of argument: a text and reader. United States of America: Bedford Books of St. Martin's Press.

Winahyu, Sri Kusuma. 2011. Argumen dalam teks opini majalah tempo. Depok: Universitas Indonesia. 


\section{Attachment}

Figure 1. Location of the billboard where the GOJEK's ad was installed in one of main street in Jakarta.

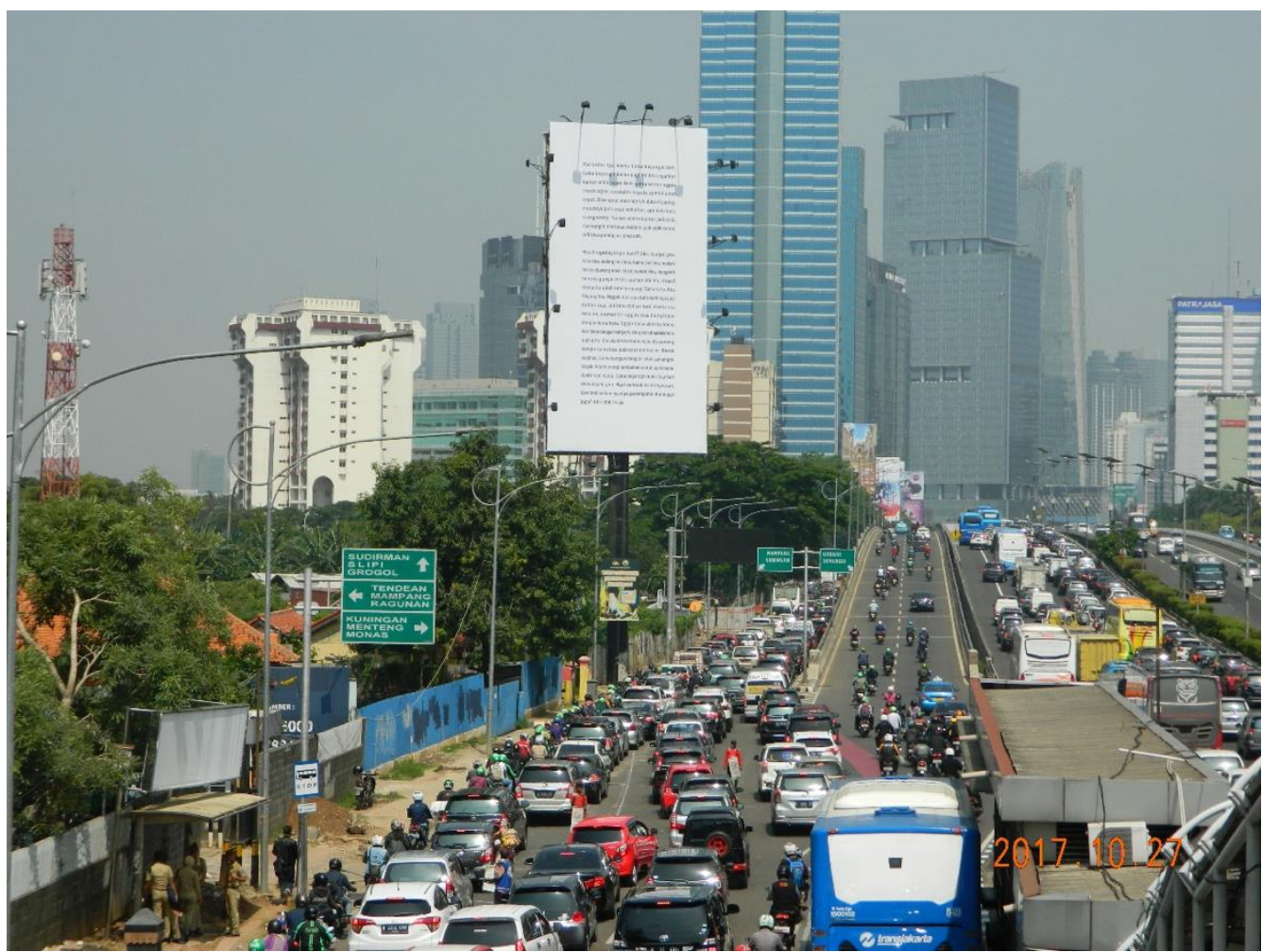

Figure 2. The text on the billboard

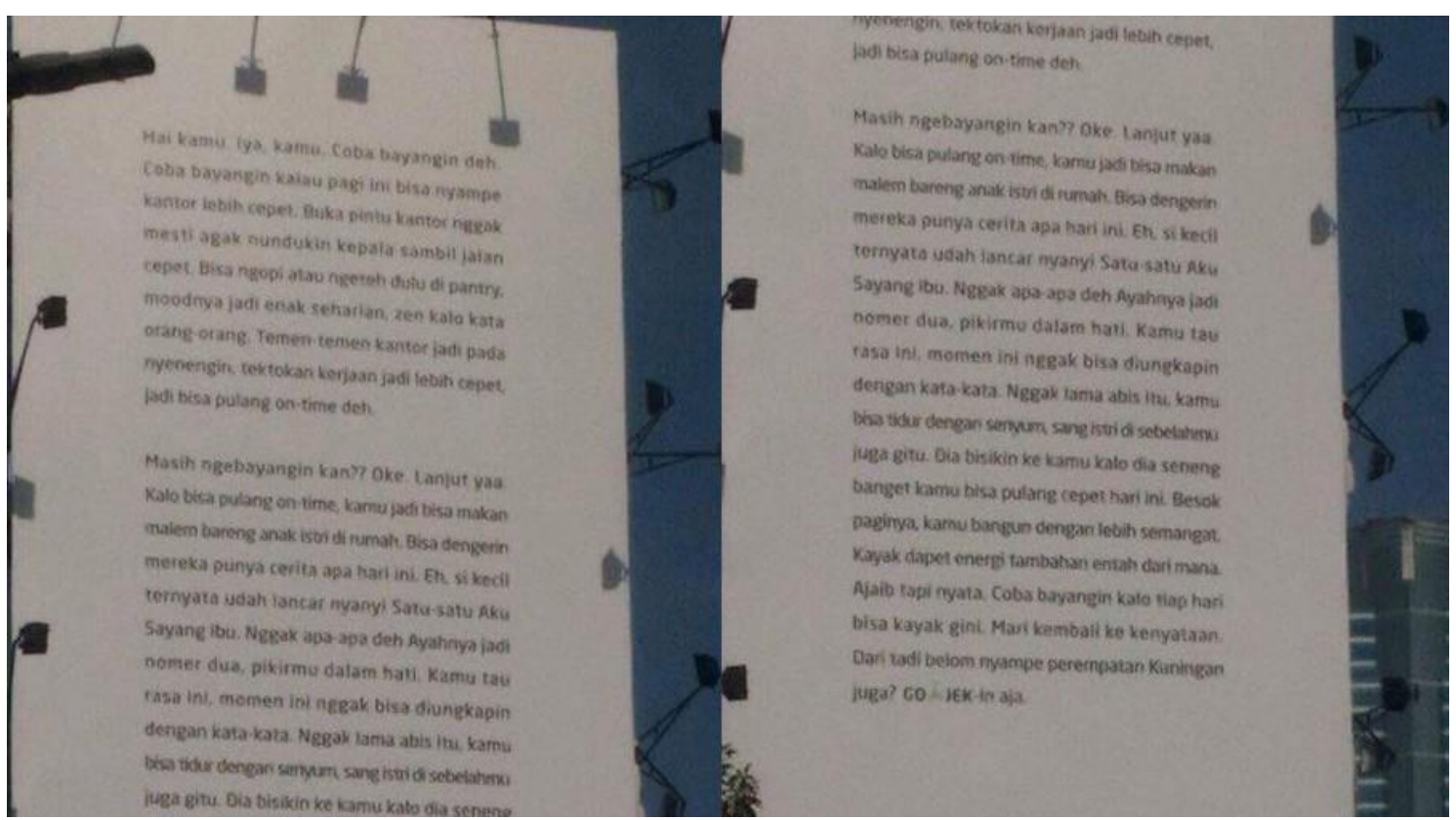

